\title{
PENGELOLAAN PIUTANG PERUSAHAAN SUB-SEKTOR MAKANAN DAN MINUMAN DI INDONESIA
}

\author{
${ }^{1}$ Winda Yuni Astuti \\ ${ }^{2}$ Yacobo P. Sijabat \\ Universitas Tidar \\ Program Studi Manajemen, Fakultas Ekonomi, Universitas Tidar \\ Windayuni1706@gmail.com ${ }^{1}$ \\ Yacobo.djabat@gmail.com $^{2}$
}

\begin{abstract}
ABSTRAK
Penelitian ini bertujuan untuk mengetahui pengelolaan piutang pada beberapa perusahaan sub sektor makanan dan minuman. Metode pengambilan sampel yang digunakan adalah metode purposive sampling. Berdasarkan metode pengambilan sampel, sampel yang dijadikan objek Percobaan adalah PT Ultra Jaya Milk Industry Tbk, PT Wilmar Cahaya Indonesia Tbk, PT Indofood Sukses Makmur Tbk, PT Mayora Indah Tbk, dan PT Multi Bintang Indonesia Tbk. Penelitian ini menggunakan data penelitian deskriptif berbasis sekunder yang diperoleh dari Bursa Efek Indonesia. Analisis data yang digunakan adalah analisis rasio piutang. Rasio piutang usaha terdiri dari tingkat perputaran piutang, jumlah rata-rata piutang, dan rata-rata penagihan piutang. Hasil penelitian menunjukkan bahwa ratarata tingkat perputaran piutang PT Indofood Sukses Makmur Tbk paling cepat. PT Indofood Sukses Makmur Tbk adalah penagihan piutang tercepat. Rata-rata jumlah piutang PT Mayora Indah Tbk adalah yang terbesar.
\end{abstract}

Kata Kunci : Perputaran piutang, Rata-rata piutang, Rata-rata pengumpulan piutang

\begin{abstract}
This study aims to determine the management of receivables in several food and beverage sub-sector companies. The sampling method used was purposive sampling method. Based on the sampling method, the samples subjected to the Experiment were PT Ultra Jaya Milk Industry Tbk, PT Wilmar Cahaya Indonesia Tbk, PT Indofood Sukses Makmur Tbk, PT Mayora Indah Tbk, and PT Multi Bintang Indonesia Tbk. This study uses descriptive secondary-based research data obtained from the Indonesia Stock Exchange. Analysis of the data used is the analysis of accounts receivable ratios. The accounts receivable ratio consists of accounts receivable turnover levels, average number of accounts receivable, and average accounts receivable collection accounts. The results showed that the average receivable turnover rate of PT Indofood Sukses Makmur Tbk was the fastest. PT Indofood Sukses Makmur Tbk is the fastest collection of receivables. The average amount of PT Mayora Indah Tbk's receivables is the largest.
\end{abstract}

Key words : Receivable Turnover, Average Receivable, Receivable Average Collection

\section{PENDAHULUAN}

Dalam setiap usaha, tingkat penjualan menjadi salah satu nilai keberhasilan dari jenis usaha yang bersangkutan. Semakin tinggi tingkat penjualan suatu perusahaan, dengan asumsi besar keuntungan yang didapat sama besar, maka semakin tinggi tingkat laba yang dihasilkan. Tujuan utama perusahaan melakukan penjualan adalah mencapai volume penjualan tertentu, 
laba maksimum, penguasaan pasar, dan kembalinya modal yang tertanam dalam jangka wakti tertentu (Swastha, 2010).

Menurut Nuruzzaman \& Arifin (2008), salah satu cara untuk meningkatkan volume penjualan, perusahaan melakukan penjualan secara kredit. Hal ini dilakukan dengan pertimbangan, apabila perusahaan menjual secara kredit maka pembeli mendapat keringanan dalam melakukan pembayaran. Hal ini memiliki daya tarik bagi pelanggan untuk terus melakukan pembelian.

Penjualan kredit yang diberikan sering disebut dengan piutang. Menurut Munawir (2002) piutang adalah hak untuk menerima kas di masa yang akan datang. Pemberian piutang bagi suatu perusahaan dapat menghasilkan keuntungan maupun kerugian bagi perusahaan itu sendiri. Penjualan kredit dapat menguntungkan karena dapat meningkatkan volume penjualan perusahaan. Namun penjualan kredit dapat merugikan perusahaan apabila pihak penerima piutang tidak selesai memenuhi kewajiban piutang yang dimiliki. Piutang merupakan pos penting karena merupakan harta yang lancar (liquid) perusahaan yang besar, oleh karena itu penting artinya untuk menetapkan kebijakan kredit yang efektif dan prosedur-prosedur penagihan untuk menjamin piutang yang tepat pada waktunya dan dapat mengurangi kerugian akibat piutang yang tidak tertagih (Nuruzzaman \& Arifin, 2008).

Menurut Nazmi (2017), piutang merupakan komponen modal kerja yang berkaitan langsung dengan kegiatan operasional perusahaan. Pengelolaan piutang yang baik akan berpengaruh terhadap keuntungan perusahaan dan pada akhirnya akan mempengaruhi profitabilitas.

Menurut Adam et al. (2015), pengelolaan piutang merupakan salah satu hal yang penting bagi perusahaan, khususnya perusahaan yang menjual produk secara kredit. Sistem pengendalian internal piutang usaha merupakan salah satu hal penting dalam menjamin keberhasilan stiap perusahaan pembiayaan dalam megumpulkan keuntungan finansial (Tahumang et al., 2017). Pengelolaan piutang (Riyanto, 2011) adalah cara untuk mengendalikan piutang dalam suatu perusahaan agar sesuai dengan anggaran yang sudah ditetapkan dan terhindar dari berbagai penyimpanan dana kas. Pengelolaan piutang yang baik berguna untuk memantau piutang agar tidak menumpuk sehingga tingkat pengembaliannya lancar. Cepat atau lambatnya pengelolaan piutang akan berpengaruh terhadap profitabilitas yang dicapai oleh perusahaan. Oleh karena itu, setiap perusahaan harus memiliki pengelolaan piutang yang baik agar dapat meningkatkat kinerja perusahaan. Cara yang digunakan untuk 
mengukur pengelolaan piutang adalah dengan menghitung berdasarkan rasio piutang. Rasio yang digunakan adalah rasio perputaran piutang, rata-rata piutang, dan rata-rata pengumpulan piutang.

Adam et al. (2015) menyatakan Perputaran piutang merupakan periode terikatnya modal dalam piutang yang tergantung kepada syarat pembayarannya. Makin lunak atau makin lama syarat pembayarannya, berarti makin lama modal terikat pada piutang, yang berarti bahwa tingkat perputarannya selama periode tertentu adalah makin rendah. Perputaran piutang adalah besarnya rasio total penjualan kredit terhadap saldo piutang rata-rata selama periode tertentu. Periode yang dimaksud biasanya untuk satu tahun (Kuswadi, 2006). Menurut Kusnadi (2001) menyatakan bahwa perputaran piutang merupakan ukuran periode rata-rata pengumpulan dari penjualan kredit. Semakin tinggi perputaran piutang maka semakin baik, karena tingginya perputaran piutang menunjukkan bahwa perusahaan semakin baik dalam melakukan pengelolaan piutang.

\section{METODE PENELITIAN}

\section{Jenis Penelitian}

Penelitian ini bersifat deskriptif komparatif, yaitu penelitian yang dilakukan dengan tujuan membandingkan analisis pengelolaan piutang antara perusahaan sejenis yang bergerak di sektor konsumsi bidang makanan dan minuman.

\section{Waktu dan Tempat Penelitian}

Untuk waktu dan tempat penelitian, penulis mengambil data sekunder yaitu laporan keuangan pada Perusahaan sub-sektor Makanan dan Minuman yang terdaftar di Bursa Efek Indonesia periode tahun 2015- 2019 melalui website www.idx.co.id.

\section{Target/Subjek Penelitian}

Populasi dalam penelitian ini adalah seluruh perusahaan sub-sektor makanan dan minuman yang terdaftar di Bursa Efek Indonesia (BEI). Sampel dalam penelitian ini adalah lima perusahaan sub-sekstor makanan dan minuman yang terdaftar dalam Bursa Efek Indonesia, yaitu PT Ultra Jaya Milk Industry Tbk, PT Wilmar Cahaya Indonesia Tbk, PT Indofood Sukses Makmur Tbk, PT Mayora Indah Tbk, dan PT Multi Bintang Indonesia Tbk.

\section{Prosedur Penelitian}

Peneliti mengidentifikasi masalah, kemudian menyimpulkan variabel yang akan di teliti. Peneliti mengumpulkan data-data yang diperlukan untuk penelitian. Setelah dilakukan penghitungan, maka peneliti menyimpulkan hasil penelitian.

\section{Data, Instrumen, dan Teknik Pengumpulan Data}


Data dalam penelitian ini adalah data sekunder. Data sekunder merupakan sumber data penelitian yang diperoleh peneliti secara tidak langsung melalui media perantara (diperoleh dan dicatat oleh pihak lain). Sumber data diambil dari website www.idx.com.

\section{Teknik Analisis Data}

Teknik analisis data yaitu menggunakan teknik analisis deskriptif. Pengertian metode deskriptif analisis menurut Sugiyono (2013) adalah statistika yang digunakan untuk menganalisa data dengan cara mendeskripsikan atau menggambarkan data yang telah terkumpul sebagaimana adanya tanpa bermaksud membuat kesimpulan yang berlaku untuk umum atau generalisasi. Analisis deskriptif merupakan analisis yang bertujuan menggambarkan serta menjelaskan tentang variabel yang dteliti dengan cara mengumpulkan data, mengolah, menganalisis, dan menginterpretasinya data sehingga dapat memberikan gambaran keadaan perusahaan secara nyata untuk kemudian bisa dijadikan dasar untuk mengajukan saran-saran perbaikan.

\section{HASIL PENELITIAN DAN PEMBAHASAN}

\section{Hasil Penelitian dan Pembahasan}

Jumlah Rata-rata Piutang

Tabel 1.2 Jumlah rata-rata piutang (dalam milyar rupiah)

\begin{tabular}{|c|c|c|c|c|c|c|}
\hline Perusahaan & 2015 & 2016 & 2017 & 2018 & 2019 & Rata-rata \\
\hline ULTJ & 448,1 & 462,4 & 504,6 & 530,4 & 613,2 & 511,74 \\
\hline perubahan $(\%)$ & & $3,2 \%$ & $9,1 \%$ & $5,1 \%$ & $15,6 \%$ & \\
\hline CEKA & 260,1 & 282,3 & 289,9 & 289,9 & 358,4 & 296,12 \\
\hline perubahan $(\%)$ & & $8,5 \%$ & $2,7 \%$ & $0,0 \%$ & $23,6 \%$ & \\
\hline INDF & $4.255,80$ & $4.616,80$ & $5.039,70$ & $5.401,90$ & 5.406 & 4944,04 \\
\hline perubahan $(\%)$ & & $8,5 \%$ & $9,2 \%$ & $7,2 \%$ & $0,1 \%$ & \\
\hline MYOR & $3.368,40$ & $4.364,20$ & $5.744,10$ & $5.572,80$ & $5.901,90$ & 4990,28 \\
\hline perubahan $(\%)$ & & $29,6 \%$ & $31,6 \%$ & $-3,0 \%$ & $5,9 \%$ & \\
\hline MLBI & 209,7 & 289,5 & 572,3 & 605,6 & 860,6 & 507,54 \\
\hline perubahan $(\%)$ & & $38,1 \%$ & $97,7 \%$ & $5,8 \%$ & $42,1 \%$ & \\
\hline \multicolumn{6}{|c|}{ Nilai Minimum } & 296,12 \\
\hline \multicolumn{6}{|c|}{ Nilai Maksimum } & 4990,28 \\
\hline
\end{tabular}


Berdasarkan tabel 1.2 dapat dilihat bahwa PT Mayora Indah Tbk (MYOR) memiliki rata-rata piutang terbesar, yang kemudian diikuti secara berurutan berdasarkan jumlah ratarata piutang oleh PT Indofood Sukses Makmur Tbk (INDF) di urutan kedua, PT Ultra Jaya Milk Tbk di urutan ketiga, PT Multi Bintang Indonesia Tbk di urutan keempat, dan PT Wilmar Cahaya Indonesia Tbk di urutan kelima dengan jumlah rata-rata piutang terkecil. Hal tersebut menunjukkan bahwa PT Mayora Indah Tbk (MYOR) melakukan penjualan kredit dengan kuantitas terbesar dibandingkan dengan empat perusahaan lainnya.

\section{Tingkat perputaran piutang}

Tabel 1.3 Tingkat Perputaran Piutang (dalam satuan kali)

\begin{tabular}{|c|c|c|c|c|c|c|}
\hline Perusahaan & 2015 & 2016 & 2017 & 2018 & 2019 & Rata-rata \\
\hline ULTJ & 8,586 & 9,157 & 9,535 & 10,694 & 12,196 & 10,034 \\
\hline perubahan $(\%)$ & & $6,6 \%$ & $4,1 \%$ & $12,2 \%$ & $14,0 \%$ & \\
\hline CEKA & 11,772 & 13,898 & 14,378 & 12,256 & 10,539 & 12,569 \\
\hline perubahan (\%) & & $18,1 \%$ & $3,5 \%$ & $-14,8 \%$ & $-14,0 \%$ & \\
\hline INDF & 12,957 & 13,483 & 14,196 & 14,845 & 15,492 & 14,195 \\
\hline perubahan $(\%)$ & & $4,1 \%$ & $5,3 \%$ & $4,6 \%$ & $4,4 \%$ & \\
\hline MYOR & 2,970 & 3,677 & 4,171 & 4,822 & 5,015 & 4,131 \\
\hline perubahan $(\%)$ & & $23,8 \%$ & $13,4 \%$ & $15,6 \%$ & $4,0 \%$ & \\
\hline MLBI & 5,312 & 6,430 & 6,679 & 7,191 & 7,313 & 6,585 \\
\hline perubahan $(\%)$ & & $21,0 \%$ & $3,9 \%$ & $7,7 \%$ & $1,7 \%$ & \\
\hline \multicolumn{6}{|c|}{ Nilai Minimum } & 4,131 \\
\hline \multicolumn{6}{|c|}{ Nilai Maksimum } & 14,195 \\
\hline & & & & \multicolumn{2}{|c|}{ Rata-Rata } & 9,503 \\
\hline
\end{tabular}

Berdasarkan Tabel 1.3 dapat dilihat bahwa rata-rata tingkat perputaran piutang selama tahun 2015-2019 PT Indofood Sukses Makmur Tbk (INDF) yang tertinggi, yang kemudian diikuti secara berurutan berdasarkan rata-rata tingkat perputaran piutang oleh PT Wilmar 
Cahaya Indonesia Tbk (CEKA) di urutan kedua, PT Ultra Jaya Milk Tbk (ULTJ) di urutan ketiga, PT Multi Bintang Indonesia Tbk (MLBI) di urutan keempat, dan PT Mayora Indah Tbk (MYOR) memiliki rata-rata perputaran piutang terendah. Menurut Dilla \& Rosyeni (2019) Semakin tinggi perputaran piutang menunjukkan bahwa modal kerja yang ditanamkan dalam piutang semakin rendah. Tentunya kondisi ini baik bagi perusahaan, sebaliknya jika perputaran piutang semakin rendah ada kelebihan modal kerja yang ditanamkan dalam piutang. Hal ini berarti semakin tinggi perputaran piutang maka semakin cepat tagihan yang masuk sehingga perusahaan dapat mengubah tagihan yang masuk menjadi kas. Berdasarkan Tabel 1.3 dapat dilihat bahwa PT Indofood Sukses Makmur Tbk (INDF) memiliki penagihan piutang yang paling cepat dan dapat mengubah tagihan masuk menjadi kas untuk kegiatan operasional perusahaan. Hal ini juga membuktikan bahwa PT Indofood Sukses Makmur Tbk (INDF) memiliki pengelolaan piutang yang baik.

\section{Rata-rata Pengumpulan piutang}

Tabel 1.4 Rata-rata Pengumpulan Piutang (dalam satuan hari)

\begin{tabular}{|c|c|c|c|c|c|c|}
\hline Perusahaan & 2015 & 2016 & 2017 & 2018 & 2019 & Rata-rata \\
\hline ULTJ & 41,928 & 39,315 & 37,755 & 33,662 & 29,517 & 36 \\
\hline perubahan $(\%)$ & & $-6,2 \%$ & $-4,0 \%$ & $-10,8 \%$ & $-12,3 \%$ & \\
\hline CEKA & 30,580 & 25,903 & 25,038 & 29,373 & 34,158 & 29 \\
\hline perubahan $(\%)$ & & $-15,3 \%$ & $-3,3 \%$ & $17,3 \%$ & $16,3 \%$ & \\
\hline INDF & 27,783 & 26,701 & 25,359 & 24,250 & 23,238 & 25 \\
\hline perubahan $(\%)$ & & $-3,9 \%$ & $-5,0 \%$ & $-4,4 \%$ & $-4,2 \%$ & \\
\hline MYOR & 121,232 & 97,902 & 86,301 & 74,665 & 71,783 & 90 \\
\hline perubahan $(\%)$ & & $-19,2 \%$ & $-11,8 \%$ & $-13,5 \%$ & $-3,9 \%$ & \\
\hline MLBI & 67,765 & 55,991 & 53,903 & 50,064 & 49,231 & 55 \\
\hline perubahan $(\%)$ & & $-17,4 \%$ & $-3,7 \%$ & $-7,1 \%$ & $-1,7 \%$ & \\
\hline \multicolumn{6}{|c|}{ Nilai Minimum } & 25 \\
\hline \multicolumn{6}{|c|}{ Nilai Maksimum } & 90 \\
\hline \multicolumn{6}{|c|}{ Rata-Rata } & 47 \\
\hline
\end{tabular}


Berdasarkan Tabel 1.4 dapat dilihat bahwa rata-rata pengumpulan piutang tahun 2015-2019 yang tercepat adalah PT Indofood Sukses Makmur Tbk (INDF), yang kemudian diikuti secara berurutan berdasarkan rata-rata pengumpulan piutang oleh PT Wilmar Cahaya Indonesia Tbk (CEKA) di urutan kedua, PT Ultra Jaya Milk Tbk (ULTJ) di urutan ketiga, PT Multi Bintang Indonesia Tbk (MLBI) di urutan keempat, dan PT Mayora Indah Tbk (MYOR) di urutan kelima dengan rata-rata pengumpulan piutang terlama.

\section{KESIMPULAN DAN IMPLIKASI}

Berdasarkan hasil analisis keuangan ke enam perusahaan sub-sektor makanan dan minuman tersebut selama lima tahun yaitu dari tahun 2015 sampai dengan tahun 2019, maka penulis dapat menarik kesimpulan dan memberikan saran-saran yang kiranya bermanfaat bagi perusahaan khususnya permasalahan pengelolaan piutang.

1. Jumlah rata-rata piutang PT Mayora Indah Tbk merupakan yang terbesar dibandingkan dengan perusahaan lainnya. Meskipun memiliki jumlah rata-rata piutamg yang terbesar, PT Mayora Indah Tbk memiliki tingkat perputaran piutang terendah. Hal tersebut menujukkan bahwa pengelolaan piutangnya masih kalah dengan perusahaan lainnya dan dapat menyebabkan piutang tak tertagih.

2. Rata-rata tingkat perputaran piutang PT Indofood Sukses Makmur Tbk berada pada posisi tercepat diantara lima perusahaan lainnya. Meskipun jumlah rata-rata piutang PT Indofood Sukses Makmur Tbk lebih sedikit daripada PT Mayora Indah Tbk, tetapi adanya manajemen piutang yang baik dari PT Indofood Sukses Makmur Tbk membuat pengembalian piutang menjadi kas kembali lebih cepat. Hal tersebut dapat meningkatkan kinerja perusahaan PT Indofood Sukses Makmur Tbk.

3. Rata-rata pengumpulan piutang PT Indofood Sukses Makmur Tbk berada di posisi yang paling cepat diantara lima perusahaan lainnya. Perusahaan mengendalikan dengan baik bagaimana cara penagihan piutang kepada pelanggan sehingga penyelesaian piutang perusahaan dapat dilakukan dengan cepat.

Berdasarkan analisis yang telah dilakukan dan dari kesimpulan yang di dapat, maka rekomendasi yang dapat penulis berikan adalah:

1. PT Wilmar Cahaya Indonesia Tbk

PT Wilmar Cahaya Indonesia Tbk disarankan untuk memperbanyak jalinan kerja sama usaha dengan perusahaan baru dengan kinerja keuangan yang baik sehingga meningkatkan daya tawar terhadap harga jual produk. Jumlah piutang PT Wilmar 
Cahaya Indonesia Tbk merupakan jumlah piutang terkecil diantara perusahaan lainnya. Perusahaan diharapkan dapat melakukan strategi persuasif untuk menciptakan terjadinya transaksi baru untuk meningkatkan penjualan perusahaan. Pengendalian biaya yang efisien harus menjadi perhatian bagi manajemen perusahaan. Perusahaan dapat melakukan penambahan investasi di bidang piutang jika perusahaan mampumengendalikan pembayaran pelanggan mengingat $\mathrm{BW}$ Plantation Tbk merupakan perusahaan dengan rata-rata pengumpulan piutang tercepat.

2. PT Mayora IndahTbk

PT Mayora Indah Tbk memberikan proporsi yang besar dalam melakukan investasi piutang. Namun kelebihan ini tidak disertai dengan manajemen pengelolaan piutang yang baik dalam melakukan penagihan terhadap pelanggan. Sehingga banyaknya pelanggan yang melakukan penunggakan pembayaran kewajiban. Perusahaan harus lebih selektif dalam memberikan piutang terhadap pelanggan dengan cara melakukan analisa laporan keuangan perusahaan pelanggan. Perusahaan dapat melakukan kunjungan personal kepada pelanggan yang menunggak untuk mempererat hubungan emosional. Namun bila cara ini tidak efektif, perusahaan dapat melakukan tindakan yuridis sesuai dengan hukum yang berlaku.

\section{DAFTAR PUSTAKA}

Adam, M., Taufik, \& Sutanto, E. Y. (2015). PENGELOLAAN PIUTANG PERUSAHAAN SUB-SEKTOR PERKEBUNAN DI INDONESIA. Jurnal Manajemen Dan Bisnis Sriwijaya, 13(4), 560-583.

Kusnadi. (2001). Manajemen Keuangan Perusahaan. PT Raja Grafindo Persada.

Kuswadi. (2006). Memahami Rasio-Rasio Keuangan bagi Orang Awam. PT Elex Media Komputindo.

Munawir. (2002). Akuntansi Keuangan dan Manajemen. BPFE.

Nuruzzaman, M., \& Arifin, M. (2008). Evaluasi atas Akuntansi Piutang dan Kaitannya atas Penyajian Laporan Keuangan: Studi kasus pada PT . Sinar Sosro. Jurnal Ilmiah Kesatuan, 10(1), 69-73.

Riyanto, B. (2011). Dasar-dasar Pembelanjaan Pembelanjaan Perusahaan. Yogyakarta:

BPFE Yogyakarta.

Sugiyono. (2013). Memahami Penelitian Kualitatif. Alfabeta.

Swastha, B. (2010). Manajemen Penjualan (3rd ed.). BPFE. 
Tahumang, S., Ilat, V., \& Runtu, T. (2017). Analisis Sistem Pengendalian Internal Piutang Usaha Pada Pt. Hasjrat Abadi Toyota Cabang Manado. Going Concern : Jurnal Riset Akuntansi, 12(2). https://doi.org/10.32400/gc.12.2.17549.2017 